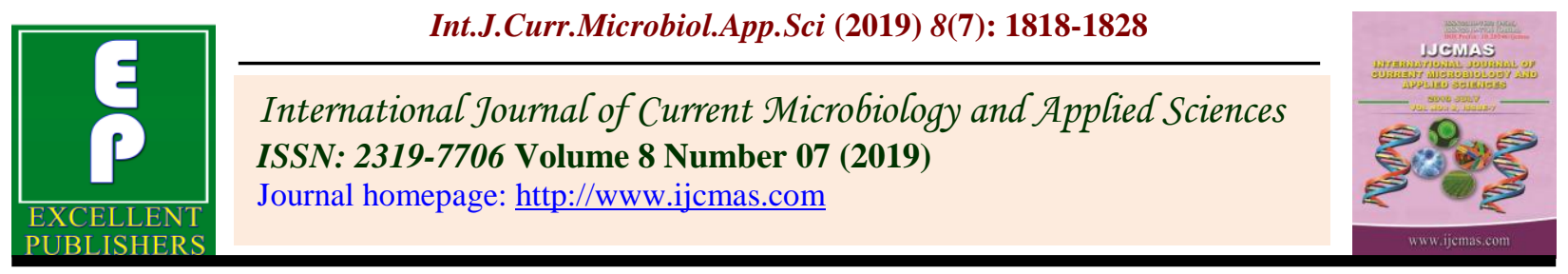

Original Research Article

https://doi.org/10.20546/ijcmas.2019.807.216

\title{
To Study HCN Production by French bean (Phaseolus vulgaris) Accessions and Their Potential to Resistance against Anthracnose
}

\author{
M. Aditya Gokul Krishna, Mohammad Salman* and Deepti Prabha
}

Department of Seed Science and Technology, H.N.B. Garhwal University, India

*Corresponding author

\section{A B S T R A C T}

Keywords

HCN Production, Correlation between Disease and HCN, Disease resistance against Anthracnose

Article Info

Accepted:

15 June 2019

Available Online:

10 July 2019
Frenchbean, Phaseolus vulgaris L. $(2 \mathrm{n}=2 \mathrm{x}=22)$ is one of the most important leguminous vegetable grown for its tender fleshy green pods, shelled green seeds, and also dry beans. Cyanogenesis has been one of the important factors of plant defense mechanism. Many plants liberate HCN after mechanical or chemical injury to their cells or in course of fungal infection. The objective of current study was to correlate between the disease resistance against Anthracnose and $\mathrm{HCN}$ production in Frenchbean. The study was based on method of $\mathrm{HCN}$ estimation using picrate strips and their quantitative estimation through Cyanogen Kit Colour Chart (ppm) and by estimating the absorbance of picrate solution and Standard Curve of absorbance against $\mathrm{HCN}$ concentration $(\mu \mathrm{g} / \mathrm{ml})$. According to the results the highest $\mathrm{HCN}$ content has been seen in lines $\mathrm{L}$ line and $\mathrm{D}$ line.

\section{Introduction}

Frenchbean, Phaseolus vulgaris L. $(2 \mathrm{n}=2 \mathrm{x}$ =22) also known as Snapbean, Kidney Bean, Garden Bean, or String Bean, is one of the most important leguminous vegetable grown for its tender fleshy green pods, shelled green seeds, and also dry beans (Praveen Kumar Angadi et al.,). It has anti diabetic property and is good for natural cure of bladder burns and cardiac problems, diarrhoea, sciatica and tenesmus. It is nutritive vegetable rich in protein $(1.7 \mathrm{~g})$, calcium (132 $\mathrm{mg})$, Thiamine (0.08 mg), and vitamin C (24 mg for 100 grams of edible pods). French Bean is originated from Central America and Peruvian Andes in South America. It spread to Europe during 16th and 17th centuries and reached England by 1594 . It was introduced in India during century from Europe. The statistics with respect to this crop is very deficient owing to the small area of production and short duration. However as per FAO estimates it is grown in world in an area of $0.83 \mathrm{~m}$ ha with annual production of $5.64 \mathrm{~m} \mathrm{t}$ with productivity of 6.76 tons per hectare. In India French bean is mainly grown in Himachal Pradesh, Punjab, Haryana, Uttar Pradesh, Gujarat, Madhya Pradesh, Maharashtra, Andhra Pradesh, Karnataka, Tamil Nadu. 
French Bean is grown in an area of $0.15 \mathrm{~m}$ ha with annual production of $0.42 \mathrm{~m} \mathrm{t}$ and productivity of $2.8 \mathrm{t}$ per ha(FAO STAT, 2002).

French bean is susceptible to many fungal and bacterial diseases like Anthracnose, Powdery mildew, Bacterial brown spot, Bacterial wilt. But several resistant lines of Frenchbean are capable producing $\mathrm{HCN}$, which acts as a defence mechanism against different kinds of diseases. Anthracnose is one of the commonly occurring disease, in this experiment, An afford was made to correlate between the disease resistance against Anthracnose and $\mathrm{HCN}$ production in French Bean.

Anthracnose is mainly a seed borne disease caused by a fungus which has a wide host range on many legume species. It is caused by Colletotrichum lindemuthianum. The disease can cause a serious loss in bean crops in temperate and subtropical zones. Leaves, stems, and pods of bean plants are susceptible to infection. Small reddish brown, slightly sunken spots from on the pods and rapidly develop into large, dark sunken lesions. I moist weather, masse of pink spores develop on lesions. Black sunken spots, similar to those on pods are developed on stems and leaf stalks. Infection of leaves cause blackening along the veins, particularly on the under surface (Elizabeth Minchinton, Knoxfield 1999). The fungus can survive on contaminated seed and on crop debris for at least two years. Development of the disease is most rapid in warm, damp conditions. Symptoms appear between 18 and $25^{\circ} \mathrm{C}$ but are delayed or prevented by temperatures outside the range of 7-33 C (Elizabeth Minchinton, Knoxfield, 1999).

Cyanogenesis is ability of plants to release hydrogen cyanide, has been known for several centuries. Since its first description in plants in 1803, the phenomenon of Cyanogenesis was recognised in 3000 species of higher plants distributed throughout 110 different families of ferns, gymnosperms, and both monocots and dicots (Conn, 1981). However, only in approximately 300 plant species has the source of HCN has been identified. In certain sapindaceous seeds HCN may arise cyanolipid hydrolysis. More frequently HCN production in higher plants results from the catabolism cyanogen glycosides. All higher plants probably low levels of HCN as a co-product of ethylene biosynthesis (Kende, 1989). Many economically important food plants are highly capable of acute cyanide poisoning of animals including man. Additionally in areas of the world where cassava and lima beans comprise major items of diet, chronic cyanide poisoning and associated pathological conditions still exist (Poulton, 1989).

Weakly cyanogenic plants liberate only small amounts of HCN against which their detoxification reaction provide sufficient protection. However, in strongly cyanogenic plants the liberation of $\mathrm{HCN}$ is rapid and the resulting $\mathrm{HCN}$ concentration in the leaves is too large to be detoxified immediately by plants. Consequently the plant defence responses will be hampered. The susceptible, highly cyanogenic plants posses the same genetic potential for the defence reactions as weakly cyanogenic plants but are inhibited by HCN produced endogenously in course of tissue colonization.

The anthracnose of common bean was first identified in the fruit and vegetable garden of the agriculture institute of Popplesdorf Germany by Lindemuth. By 1878, Saccardo and Magnus had made many observations on the cause of anthracnose disease, recording their results in Michelia. They concluded that it was caused by a fungus, which they named Gloeosporium lindemuthianum after Lindemuth himself. Several years later, Briosi and Cavara discovered the presence of setae 
on the fungus, reclassifying it from Gloeosporium to Colletotrichum.

\section{Materials and Methods}

\section{Culture of Anthracnose}

Anthracnose culture was developed from the infested leaves of French bean in lab. Diseases isolates have been collected from experimental fields. Isolated plant parts have been cut into small bits and surface sterilized with0.1 percent mercuric chloride $(\mathrm{HgCl} 2)$ solution for about one minute and washed repeatedly thrice in sterile distilled water before transferring them to sterile petriplates containing PDA media $(5 \mathrm{~mm})$ under LF (laminar air flow chamber). Excess water has been wiped of sterile tissue paper. Petriplates containing diseased plant parts were kept in a room temperature for seven to ten days under aseptic conditions and observed at regular intervals for growth of the pathogen. After the incubation period, fungal pathogens were observed under compound microscope. For purification of the cultures, single spore isolation technique was followed pure culture was prepared for getting species purity. Subcultures was prepared in media slants for conducting experiments without disturbing pure culture. Slants of pure cultures have been kept in refrigerator at 5 degrees Celsius for storage. Sub culturing was done subsequently at an interval of 30 days in order to maintain virulence of culture purpose. Three weeks old plants were inoculated with spore suspension (106 conidia/ml) of pathogen $C$. lindemuthianum to check for resistance against $C$. lindemutianum.

Total seven different types of French Bean were taken for the estimation, out of which six were collected from Garhwal region of Uttarakhand, they are L line, D line, GFB 24, GFB 22, GFB 30. The remaining two falguni, Mridula which are common varieties that are under cultivation. The disease resistance of four lines L line, D line, and GFB 24, GFB 30 is known and line GFB 22, is susceptible line. The disease resistance of remaining two Falguni, Mridula is unknown. Two replicates of each line were taken. The seeds are sown in the pots of medium size which are filled with soil. The soil should be mixed with the farm yard manure to prevent the malnutrition of the plants. Five seeds of each line are sown in the three pots. The seeds are sown at a depth of $5 \mathrm{~cm}$ (2inches) for better and faster germination. The seeds should be watered immediately after sowing, the pots should not be over flooded to prevent rotting and optimum amount of water should be given to seeds for better germination. The pots are placed where sunlight is abundant and they should be watered alternate days. The seeds are germinated within one week, after the seedlings become one month older they are grown under controlled conditions (Fig. 1 and 2).

\section{Method of HCN Determination}

The method of $\mathrm{HCN}$ estimation was essentially derived from that of Nowosad and Mc Vicar. The procedure was as follows: The above method was altered with slight modifications according to requirements and resources available. The Whatman filter paper is cut into strips of $1.5 \mathrm{~cm}$ wide and $5 \mathrm{~cm}$ in length for making picrate strips. After this the $100 \mathrm{ml}$ picrate solution is made by dissolving 2.5 grams of sodium carbonate and 0.5 grams of picric acid in $100 \mathrm{ml}$ of distilled water. The solution is mixed thoroughly until the sodium carbonate and picric acid. A clear yellow coloured solution is obtained after thorough mixing. The solution is kept in dark or shady conditions until it is used. The strips of filter paper are now dipped in the picrate solution, taken out and kept aside in dark to dry them slightly. The test tube with closed lids is used in this method instead of vials. The chloroform is taken into a beaker and is closed 
with aluminium foil to prevent it from evaporation. The whole equipment is kept in box in shade and taken directly to the field where the pots of French bean are present. The leaves of medium size from each replicate of each line are taken and placed in the test tube. A drop of chloroform of $0.5 \mathrm{ml}$ is dropped on the leaf with help of micro pipette. The preprepared picric acid strips are placed above leaf without touching the leaf, the whole procedure should be carried out inside box in shady conditions. The test tubes with leaves and picric acid strips are immediately taken to seed germinator, placed in dark and at a temperature of 25 for 48 hours. After 48 hours the picric acid strips are checked for the reddish colour which is proportional to the $\mathrm{HCN}$ production.

\section{Semi quantitative determination of cyanide using picrate paper}

Following the qualitative assay, the picrate papers were soaked in $5 \mathrm{ml}$ of distilled water for 3 minutes to prepare picrate solution. Absorbance of picrate solution was read at $510 \mathrm{~nm}$ using U.V. visible spectrophotometer. The linear calibration curve of cyanide used to determine HCN content in French Bean sample was as drawn in figure 3.

\section{Qualitative determination of cyanide using picrate paper}

The colour of picrate papers matched against the colour chart shown in the figure 4 for the qualitative determination of Cyanide in ppm. This procedure was repeated for the blank (same procedure was used with no French bean/ HCN put in the bottle) and the standard HCN solution.

\section{Data analysis}

The obtained data tabulated and expressed as standard error of the mean. The student $T$ test was employed to determine statistical significance of obtained results (Table 1-3).

\section{Ethical considerations}

All reagents and chemicals were handled and disposed of according to the set laboratory regulations. Good laboratory practice was upheld to ensure safety.

\section{Results and Discussion}

Estimated cyanide content in parts per million from colour chart

The lines L Line, D Line, had shown HCN concentration of $10 \mathrm{ppm}$ before infection and after infection $65 \mathrm{ppm}$ and $60 \mathrm{ppm}$ respectively. The varieties falguni and Mridula had shown HCN content of $12 \mathrm{ppm}, 15 \mathrm{ppm}$ before infection and $50 \mathrm{ppm}, 30 \mathrm{ppm}$ after infection respectively. The lines GFB 22, GFB 30 had shown $\mathrm{HCN}$ content of 5 ppm before infection and after infection 5 ppm and 50 ppm.

The Line GFB 24 has shown a HCN concentration of $10 \mathrm{ppm}$ before infection and $50 \mathrm{ppm}$ after infection. The results are given in Table 2.

\section{Determined cyanide content from the picrate paper}

Spectrophotometric determination of the picrate papers demonstrated that the disease resistant lines Line L, Line D, GFB 24, and varieties Falguni, Mridula demonstrated cyanide concentrations of $0.13 \mu \mathrm{g} / \mathrm{ml}$ before infection and $0.15,0.15,0.14,0.14,0.13 \mu \mathrm{g} / \mathrm{ml}$ after infection respectively. The Line 22 has shown cyanide production of $0.12 \mu \mathrm{g} / \mathrm{ml}$ before infection and $0.12 \mu \mathrm{g} / \mathrm{ml}$ after infection. The line GFB 30 has shown a HCN content of $0.12 \mu \mathrm{g} / \mathrm{ml}$ before infection and $0.14 \mu \mathrm{g} / \mathrm{ml}$ after infection (Table 3). 
Table.1 Values for standard calibration curve Preparation

\begin{tabular}{|l|c|c|}
\hline \multirow{2}{*}{ Line } & \multicolumn{2}{|c|}{ Absorbance } \\
\cline { 2 - 3 } L line & Before Infection & After Infection \\
\hline D line & 0.160 & 0.286 \\
\hline Falguni & 0.160 & 0.281 \\
\hline Mridula & 0.161 & 0.250 \\
\hline GFB 24 & 0.163 & 0.230 \\
\hline GFB 22 & 0.160 & 0.251 \\
\hline GFB 30 & 0.150 & 0.157 \\
\hline
\end{tabular}

Table.2 Values of HCN content obtained using colour chart

\begin{tabular}{|c|c|c|c|}
\hline \multirow{2}{*}{ Line } & \multicolumn{2}{|c|}{ Concentration in ppm } & t calculated \\
\hline L line & Before Infection & After Infection & \\
\hline D line & $10 \mathrm{ppm}$ & $65 \mathrm{ppm}$ & \\
\hline falguni & $10 \mathrm{ppm}$ & $60 \mathrm{ppm}$ & \\
\hline Mridula & $12 \mathrm{ppm}$ & $50 \mathrm{ppm}$ & 4.41 \\
\hline GFB 24 & $15 \mathrm{ppm}$ & $30 \mathrm{ppm}$ & \\
\hline GFB22 & $10 \mathrm{ppm}$ & $50 \mathrm{ppm}$ & \\
\hline GFB 30 & $5 \mathrm{ppm}$ & $5 \mathrm{ppm}$ & \\
\hline
\end{tabular}

Table.3 Values of concentration of HCN obtained using spectrophotometer

\begin{tabular}{|c|c|c|c|}
\hline \multirow{2}{*}{ Line } & \multicolumn{2}{|c|}{ Concentration $\boldsymbol{\mu g} / \mathbf{m l}$} & t calculated \\
\cline { 2 - 4 } & Before Infection & After Infection & \\
\hline L line & 0.13 & 0.15 & \\
\hline D line & 0.13 & 0.15 & \\
\hline falguni & 0.13 & 0.14 & 2.57 \\
\hline Mridula & 0.13 & 0.13 & \\
\hline GFB 24 & 0.13 & 0.14 & \\
\hline GFB 22 & 0.12 & 0.12 & \\
\hline GFB 30 & 0.12 & 0.14 & \\
\hline
\end{tabular}


Fig.1 Culture of Anthracnose

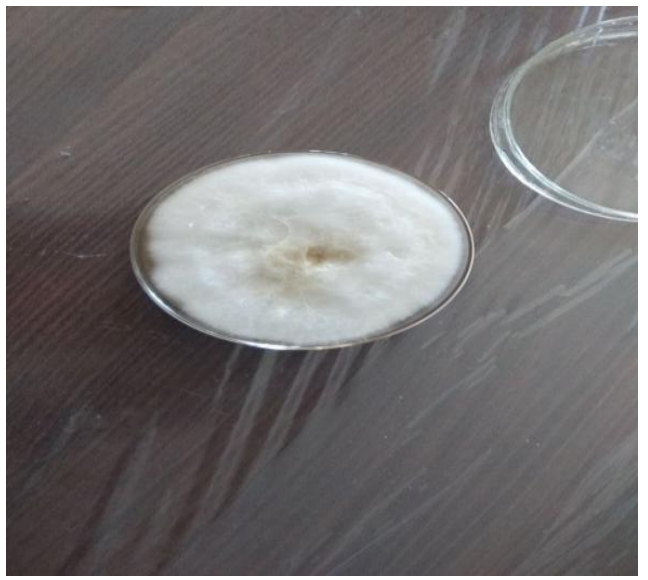

Fig.2 French bean leaf infected with anthracnose

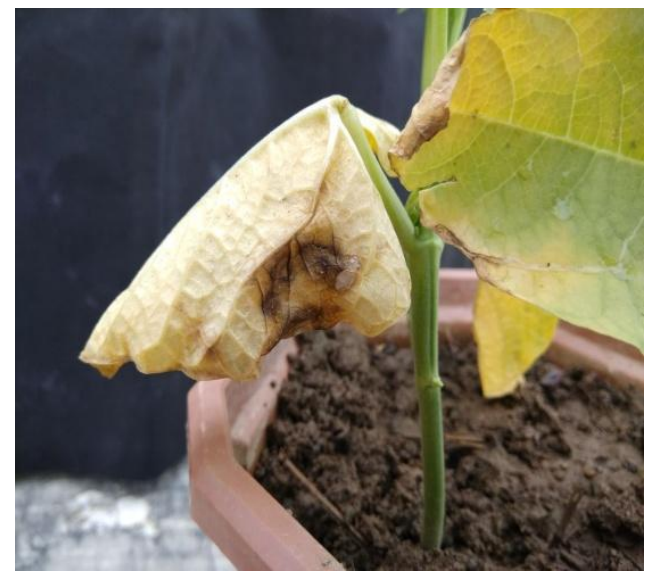

Fig.3 A standard curve of absorbance against HCN concentration

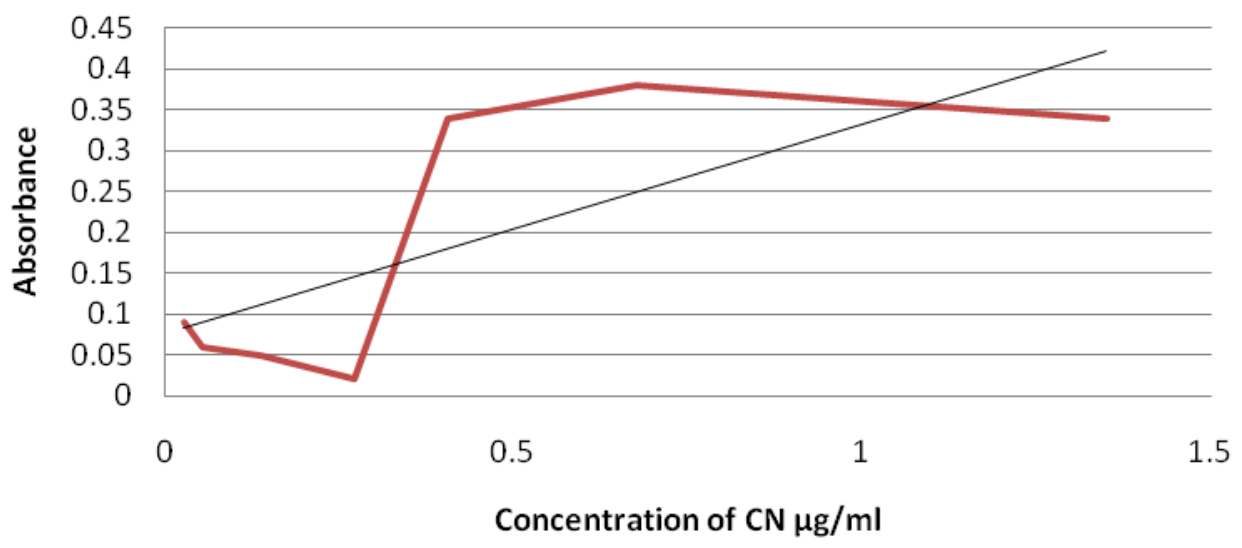

- absorbance L Linear (absorbance)

Fig.4 Cyanogen kit colour chart

\section{CASSAVA CYANOGEN IKIT COLOUR CHART}

20

30

50

$100200400800 \mathrm{ppm}$

1 ppm = 1 milligram hydrogen cyanide (HCN) per kilogram cassava

Dx. J. II. Bradbury, School of Botany \& Zoology, Australian National Univeraity, Canberra, ACT, Australia, OzOO Fax: $+61-2-6125$ 0775; omai1: Howand Bradbury colann edn.an 
Fig.4 One month old plant of different French bean accessions before infection of Colletotrichum lindemuthianum (Anthracnose)
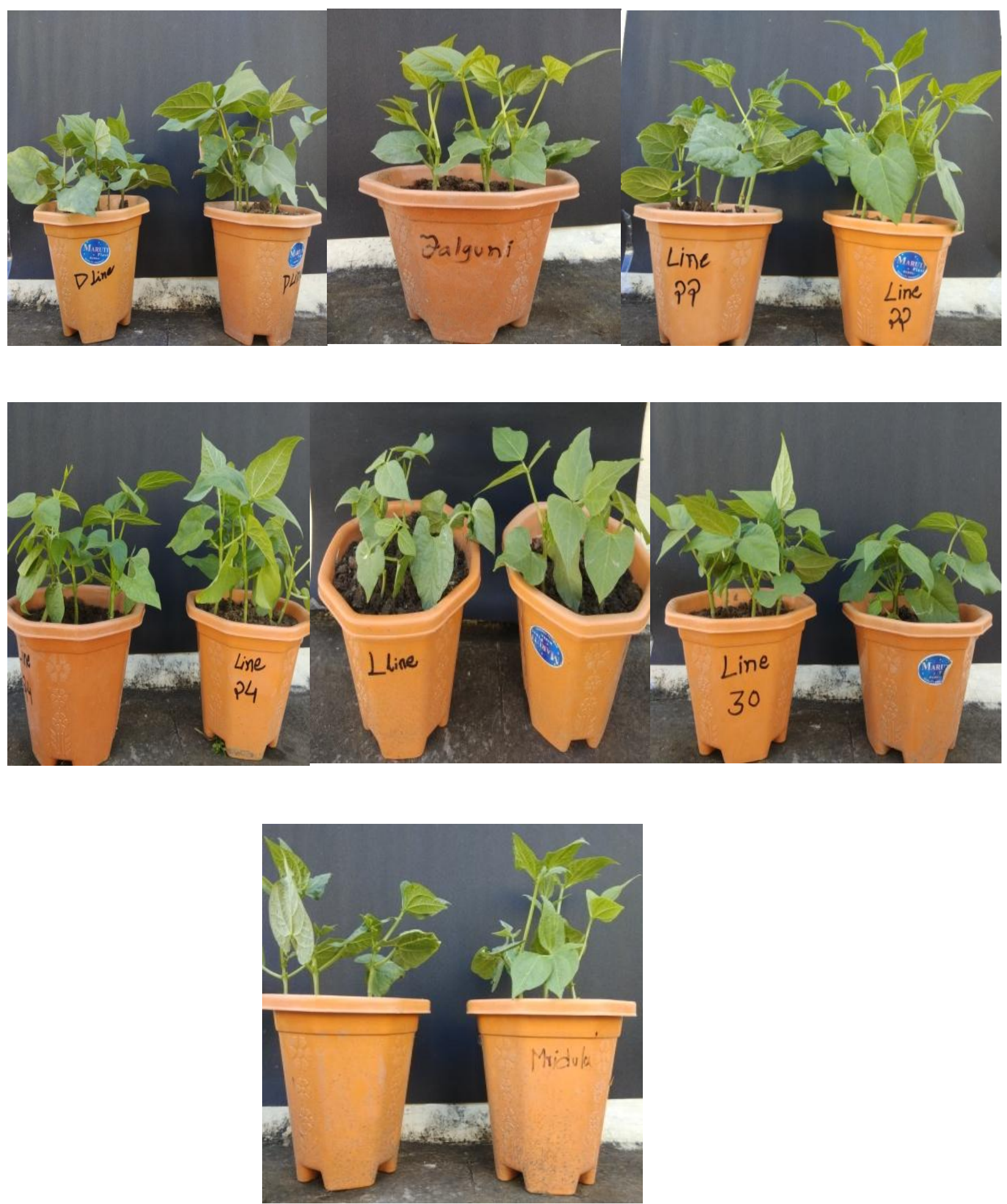
Fig.5 Effect of anthracnose fungus on French bean plants after 10 days of artificial inoculation of anthracnose culture
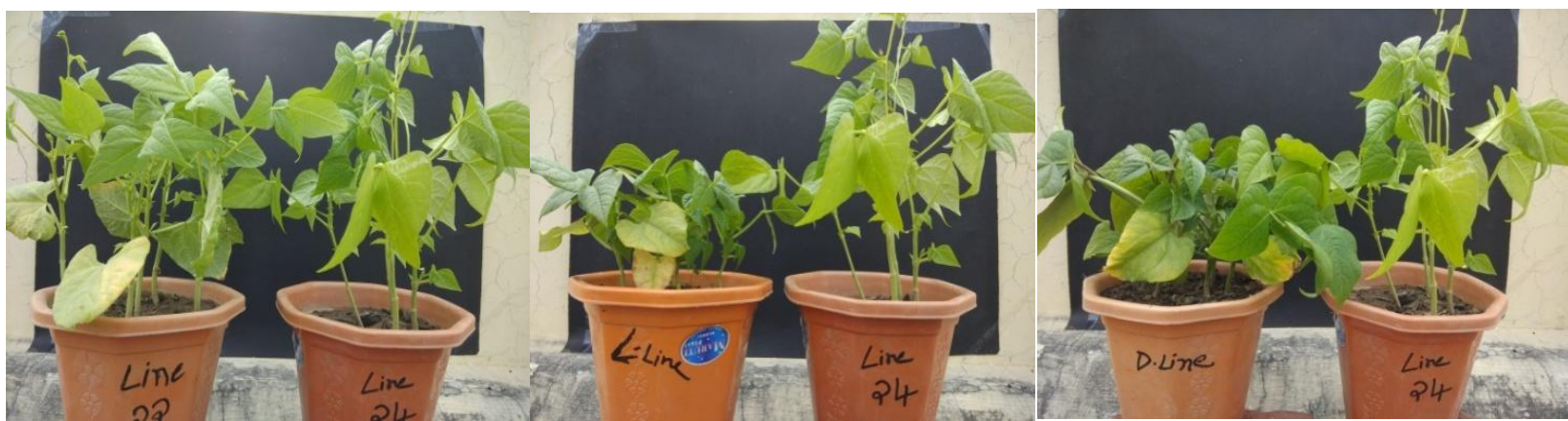

One month old plants were inoculated with the culture of anthracnose. French bean accession 24 and 30 were resistant to anthracnose in comparison to other accessions and varieties

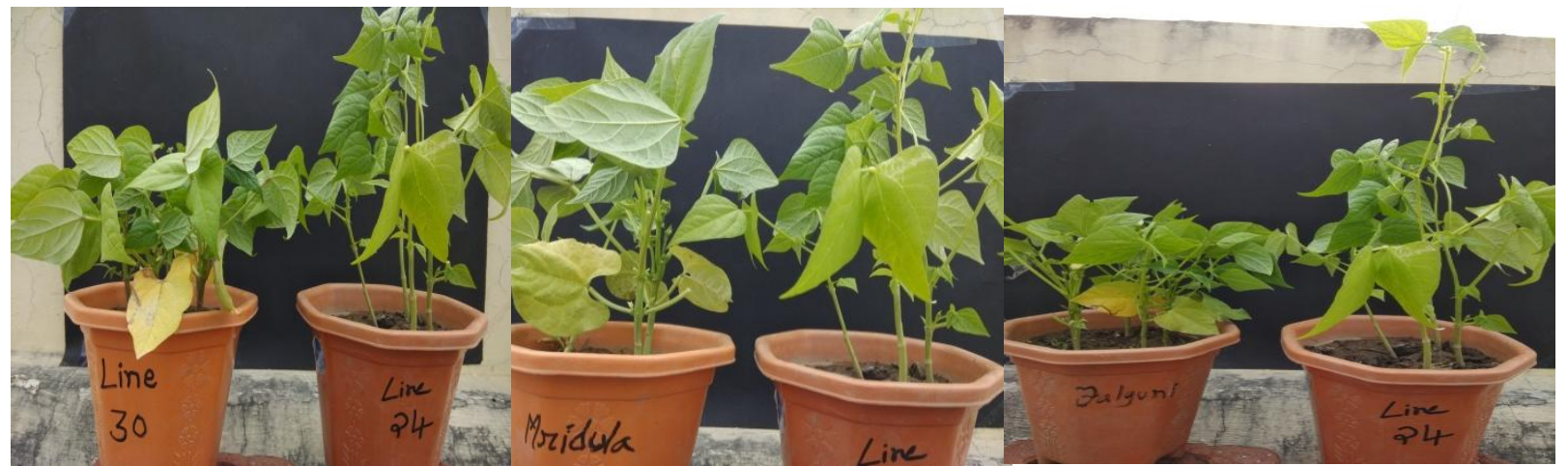

Fig.6 HCN production by different French bean accessions and varieties before inoculation of anthracnose

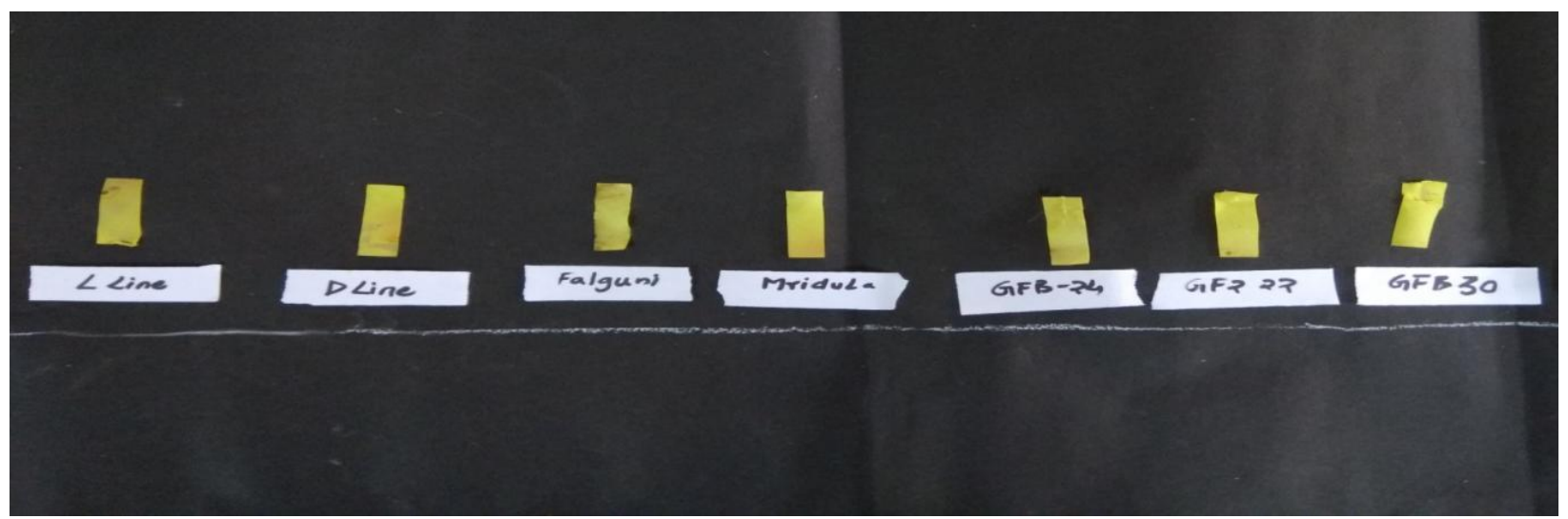

Mridula and Falguni- Cultivars, L- Line and D-line- Resistant line for anthracnose, GFB- 22, GFB24, GFB-30- French bean accessions collected from Garhwal region. 
Fig.7 HCN production by different French bean accessions and varieties after one week of inoculation of anthracnose

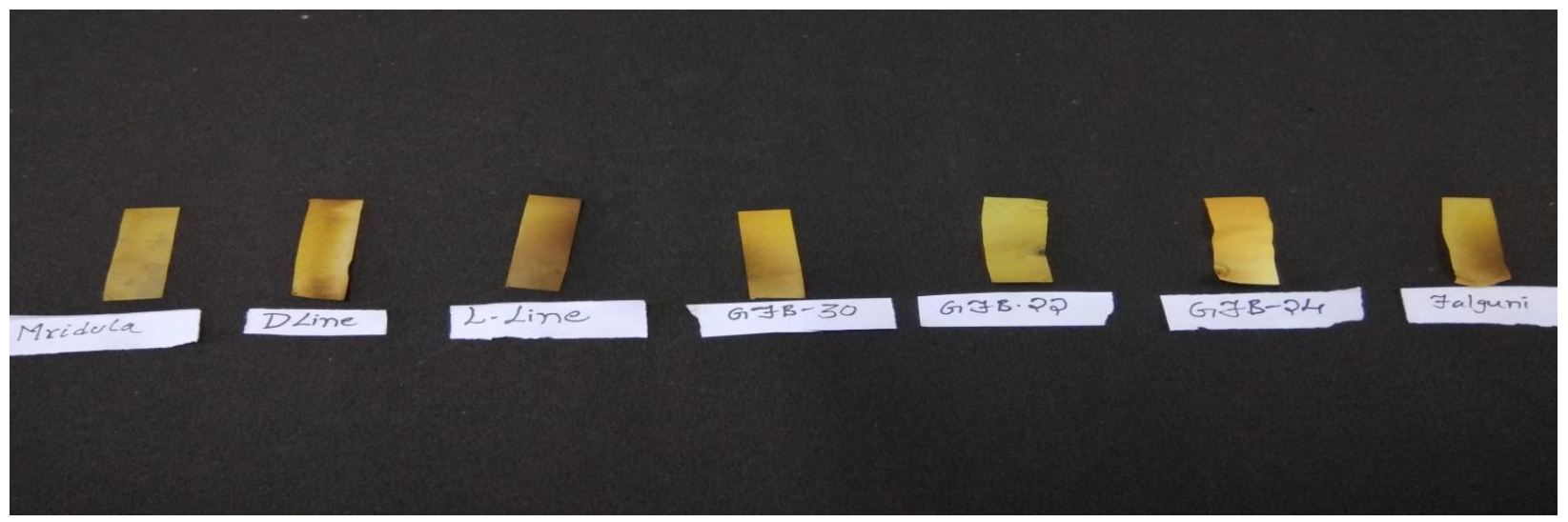

Mridula and Falguni- Cultivars, L- Line and D-line- Resistant line for anthracnose, GFB- 22, GFB24, GFB-30- French bean accessions collected from Garhwal region.

By the above values which were obtained through different methods of $\mathrm{HCN}$ estimation, it can be clearly stated that the disease resistance of lines L line, D line, GFB 24, GFB 30, and the cultivars Falguni and Mridula against Anthracnose can be directly related to $\mathrm{HCN}$ production of the given accessions. As the disease resistant lines L Line, D line had shown a highest production HCN content after infection they can be considered as highly resistant to the Anthracnose disease. Whereas remaining accessions GFB 30, GFB 24, Falguni and Mridula had also shown considerable amount of $\mathrm{HCN}$ production. So, their disease resistance can be correlated to their $\mathrm{HCN}$ production. The susceptible line GFB 22 has shown least amount of $\mathrm{HCN}$ content before and after infection which can be clearly mentioned as reason for its susceptibility for Anthracnose disease.

\section{References}

Bailey, J.A. (1992). Colletotrichum: biology, pathology and control. Pp. 88.

Bishop, L.R. The estimation of cyanogenic glucosides. Biochem. Journal 21. 1162.
1927. Clawson, A.B., Couch, James F., and Bunyea, $\mathrm{H}$. The toxicity of sodium cyanide and the efficiency of nitratethiosulphate combination as a remedy for poisoned animals. 1935 .

Boyd, F.T. the determination of the factors influencing the amounts of cyanide in Sudan grass. (Unpublished thesis on file in the University of Winsconsin library)

Bradbury, M., Egan, S., Bradbury, J.; Determination of all forms of cyanogens in cassava roots and cassava products using picrate paper kits. Journal of the Science of Food and Agriculture, 79:593-601, 1999.

Conn EE (1981) Cyanogenic glycosides. In PK Stumpf, EE Conn, eds, The Biochemistry of Plants: A Comprehensive Treatise Vol 7, Secondary Plant Products. Academic Press, New York, pp 479-500.

Cyanogenesis in Andropogeon sorghum, 1919. Jour. Agr.

Dowell, C.F. A study of Cyanogenesis in Sorghum vulgare. 1919.

Dunstan, W.R. and Henry, T.A. Cyanogenesis in plants, part 2. The great millet. Philosophical Trans. Royal Society 
London, 1902.

Elizabeth Minchinton, Knoxfield 1999, Note Number: AG0559

Evaluation of Cyanide levels in Two cassava varieties (Mariwa and Nyakatenegi) grown in Bar-agulu, Siaya County, Kenya. Moriasi Gervason A, Olela Ben O., Waiganjo Bibianne W. WakoriEdith, Onyancha Jared M. November 1, 2017.

FAO STAT, 2002.

Franzke, C.J. Diurnal variations of hydrocyanic acid, dry matter, and total sugar in sorghum strains. 1948.

Hiltner, R.S. the fatal effect of green sorghum. 1900.

Hogg, Peter G. and Ahlgren, H.L. Environmental, breeding, and inheritance studies of hydrocyanic acid in Sorghum vulgare var. sudanese 1943.

Kende H (1989) Enzymes of ethylene biosynthesis. Plant Physiol 91:1-4.

Leach, Julian Gilbert. 1922. The parasitism of Colletotrichum lindemuthianum. University of Minnesota. Retrieved 30 March 2014.

Lieberei R (1988) Relationship of cyanogenic capacity $(\mathrm{HCN}-\mathrm{c})$ of the rubber tree Hevea brasiliensis to susceptibility to Microcyclus ulei, the agent causing South American leaf blight. J Phytopathol 122: 54-67.

Lieberei R, Schrader A, Biehl B, Chee KH (1983) Effect of cyanide on Microcyclus ulei cultures. J Rubb Res Inst Malaysia 31: 227-235

Ludtke M, Hahn H (1953) Uber den Linamarin gehalt gesunder und von Colletotrichum befallener junger Leinpflanzen. Biochem Z 324: 433-442.

MacDonald, H.A. A consideration of various plants deletarious grazing livestock with special reference to cyanogenetic species. Mimeographed teaching outline, Cornell University.

Martin, J.H., Couch, J.F., and Briese, R.R. hydrocyanic acid content of different plant parts of sorghum plant. 1938.

Menual, Paul sand Dowell, C.T. Cyanogenesis in Sudan grass: A modification of the Francis- Connell method of determining hydrocyanic acid. 1920.

Mercure, E.W., H. Kunoh. R.L. Nicholson (December 1994). "Adhesion of Colletotrichum-graminicola conidia to corn leaves - a requirement for disease development". Physiological and molecular plant pathology. 45 (6): 407.

Mirande, M. Influence exerceee par certaines vapeurs surla vegetable. Procede rapide pour la recherche des plantes a siede cyanhydrique. 1908.

Nowosad, F.S and Mac Vicar, Adaptation of the "picric acid test" method for selecting HCN free lines in Sudan grass. 1940.

Peters, A.T., Slade H.B and Avery, Samuel. Poisoning of cattle by common sorghum and kafir corn. 1903.

Pinckney, R.M. Effect of nitrate applications upon the hydrocyanic acid content of sorghum. 1924.

Poulton JE (1989) Toxic compounds in plant foodstuffs: cyanogens. In JE Kinsella, WG Soucie, eds, Food Proteins. The American Oil Chemists' Society, Champaign, IL, pp 381-401.

Praveenkumar Angadi, M.G. Patil and Akshay Angadi, Path coefficient analysis studies in French bean (Phaseolus vulgaris L.)

Pynenburg, Gerard Martin. 2010. Agronomic and economic assessment of intensive pest management of dry bean. M.Sc., University of Guelph. Retrieved 4 April 2014.

Slade, H.B. A study of the enzyme of green sorghum, Nebr. Agr. Exp. Station 1902.

Stakelenburg, N.J. Physiological importance of glucosides producing hydrocyanic acid in plant metabolism. 1932. 
Swanson, C.O Hydrocyanic acid in Sudan grass and its effects on cattle. 1921.

Vinall, H.N. A study of the literature concerning poisoning of cattle by the prussic acid in sorghum, Sudan grass, and Johnson grass. 1921.
West, R.M. Effect of climatic factors on the hydrocyanic acid content of sorghum. 1916.

Willaman, J.J The estimation of Hydrocyanic acid and the probable form in which it occurs in sorghum. 1917.

\section{How to cite this article:}

Aditya Gokul Krishna M., Mohammad Salman and Deepti Prabha. 2019. "To Study HCN Production by French bean (Phaseolus vulgaris) Accessions and Their Potential to Resistance against Anthracnose". Int.J.Curr.Microbiol.App.Sci. 8(07): 1818-1828.

doi: https://doi.org/10.20546/ijcmas.2019.807.216 